\title{
DETERMINATION OF THE INFLUENCE FACTORS ON SOCIAL COMMERCE IN SME: A REVIEW
}

\author{
S. Erwin ${ }^{1,{ }^{\star}}$, N. S. A. Rahman ${ }^{1}$ and R. Awanis ${ }^{1}$ \\ ${ }^{1}$ Faculty of Computing, Universiti Malaysia Pahang, 26300 Pahang, Malaysia.
}

ABSTRACT - Social Commerce is a new form of online commerce that utilizes social media technology. Individuals and companies have become interested in utilizing Social Commerce. But, S-Commerce adoption is not easy because you have to know what factors determined SCommerce adoption. This study aims to investigate the determinants factor that influences the implementation of social commerce on SME. The results of this study are TAM and UTAUT is a method that is widely used for S-Commerce implementation, while the factors that influence the implementation of social commerce are the perceived usefulness, trust, ease of use, facilitating conditions, and information quality.

\author{
ARTICLE HISTORY \\ Received: 18 July 2020 \\ Accepted: 30 Aug 2020
}

\section{KEYWORDS}

S-Commerce

Tehnology Adoption Model

Small Medium Enterprise

\section{INTRODUCTION}

The development of E-Commerce (EC) is now utilizing social media technology. It can create collaboration between goods and services to be more intense. Activities in S-Commerce are quite fascinating because they involve social interaction between customers (Bamansoor et al., 2020; Lin et al., 2019; Solangi et al., 2019). Because of this, the term Social Commerce appears (S-Commerce). In general, S-Commerce can be said to be a subset of E-Commerce (Abed, 2020; Maia et al., 2018; Zhang \& Benyoucef, 2016). The main definition of S-Commerce is very varied. S-Commerce as a new way of doing commerce in a collaborative and participative way, involving interactions among all the actors of the value chain (Abed, 2020; Lin et al., 2019; Solangi et al., 2019).

S-Commerce is a service based on social networking technology, specifically utilizing social media. Therefore, the main activities of S-Commerce become fascinating, which include online transactions, online marketing, and customerbased content creation networks. S-Commerce has significant financial and strategic benefits for the company. These benefits can be felt by three parties including customers, enterprises, and retailers (Bamansoor et al., 2020). These benefits can be used to improve the relationship between the company and customers, especially to increase sales and marketing (Lin et al., 2019; Lin et al., 2017).

In practice, S-Commerce involves people, management, technological, and information elements (Lin et al., 2017). The concept of S-Commerce is something attractive and new. Research on this subject is still lacking but is still growing. (Abed et al., 2015; Lin et al., 2017). Although the benefits obtained are quite good, but S-commerce adoption is not easy to do, because it is difficult to determine which factors influence (Aldhahery et al., 2018). Therefore, this study determines what factors influence S-Commerce in SMEs.

\section{SOCIAL COMMERCE IN SME}

From an organizational perspective, S-Commerce has great potential. There are $87 \%$ of companies in the world that use social media. Thus, companies can benefit from online social interaction with consumers (Maia et al., 2018). The biggest benefits for companies are direct interaction with consumers, wider market reach, low adoption costs, and minimal IT skills (Abed, 2020). On the other hand, there is a Small-Medium Enterprise (SME) that has great potential in the country's economic growth but has limitations. Some limitations include the lack of financial resources, lack of information management systems, lack of expert knowledge management, and lower levels of available resources. IT adoption in SMEs is also still low (Abdulla Ali et al., 2019; Abed, 2020; Chatterjee \& Kumar Kar, 2020).

The utilization of S-Commerce provides opportunities for SMEs to improve their business. With these limitations, SMEs can market products and services, build niche markets, build trust and customer loyalty, and can manage reputation and collect marketing intelligence (Abed, 2020; Chatterjee \& Kumar Kar, 2020). Besides, S-Commerce can function as a business strategy for SMEs to manage their business. Specifically related to commercial activities such as assisting consumers in pre-purchase product evaluations, shopping decisions, and post-purchase behaviors (Lin et al., 2017).

Some things that need to be considered by SMEs for S-Commerce Adoption are expensive initiatives, risks, complex procedures, technical expatriates, and customer service (Dahnil et al., 2014). From an organizational perspective, the factors that influence the implementation of S-Commerce consist of top-level management, finance, and human resources IT capabilities. Business owners have an important role in deciding the adoption of technology in SMEs (Dahnil et al., 2014; Purwandari et al., 2019). SMEs will tend to use S-Commerce if it is less expensive and easy to use. S-Commerce 
should be able to be a bridge between SME and customers. Specifically helps in online activities for marketing prospects, comparing selling and buying to help make decisions (Chatterjee \& Kumar Kar, 2020).

\section{THEORETICAL MODEL}

The process of adopting IT in an organization is a process that is not easy and requires time to be successful (Wang et al., 2019). IT adoption is related to factors that support or hinder IT adoption in organizations. Adopters can be individuals, organizations, or inter-related organizations. There are several models related to IT acceptance and adoption (Johny \& Bhasi, 2015; Samarasinghe \& Silva, 2019). There are some common theories used in IT Adoption, the Technology Acceptance Model (TAM) and Unified Theory of Acceptance and Use of Technology (UTAUT2) (Chatterjee \& Kumar Kar, 2020; Cho \& Son, 2019; Rahman et al., 2020; Wang et al., 2019).

TAM consists of two influential factors, perceived ease of use and perceived usefulness that determines attitudes towards the use and adoption of these technologies (Davis, 1985; Johny \& Bhasi, 2015; Samarasinghe \& Silva, 2019). In the extended TAM model theory, there are additional factors, namely enjoyment, so that extended TAM has three factors, namely perceived ease of use, usefulness, and enjoyment (Cho \& Son, 2019). Several studies are using TAM for SCommerce adoption (Chatterjee \& Kumar Kar, 2020; Cho \& Son, 2019; Maia et al., 2018; Othman et al., 2019; Solangi et al., 2019). In the context of S-Commerce, three factors presented by Cho \& Son (2019), perceived ease of use, usefulness, and enjoyment are influential. The TAM model that is widely used by researchers is shown in Figure $\mathbf{1 .}$

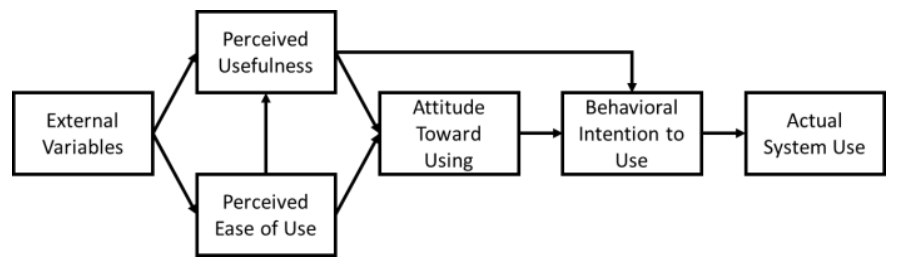

Figure 1. Factors in the TAM model (Davis, 1985)

For instance, research conducted by Chatterjee \& Kumar Kar (2020) aims to find out the influencing factors and whether there is an impact of S-Commerce adoption on SMEs in India. In that study, researchers combined TAM with UTAUT2 to get another view of technological and financial factors. Also, researchers add compatibility factors to see whether new technology can be integrated with previous technology. Researchers believe if the adoption of new technologies as they have been used then the new technology will be well adopted.

UTAUT is a common technology acceptance theory derived from TAM, Diffusion of Innovations (DOI), Theory of Reasoned Action (TRA), and Theory of Planned Behavior (TPB). The theory consists of four factors, namely performance expectancy, effort expectancy, social influence, and facilitating conditions. Also, UTAUT has a gender, age, experience, and voluntariness factors (Bamansoor et al., 2020; Rahman et al., 2020). Factors in the UTAUT model can be seen in Figure 2 .

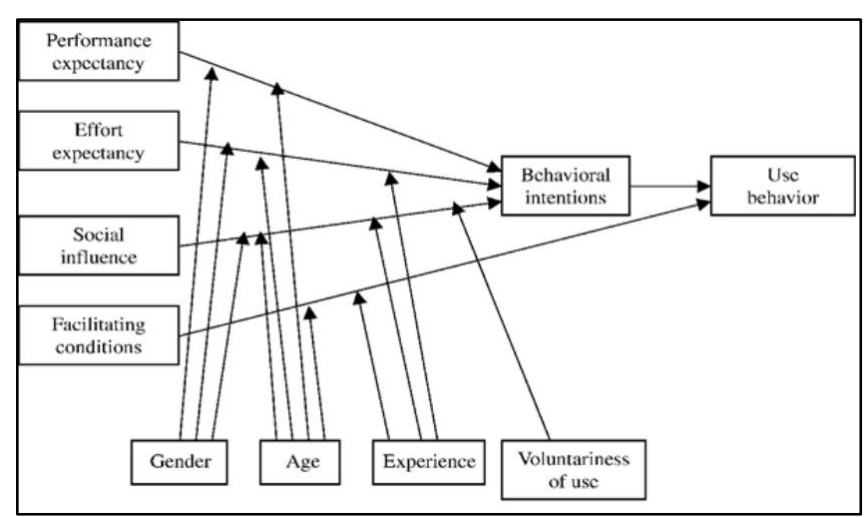

Figure 2. Factors involved in the UTAUT model (Rahman et al., 2020)

Besides, other studies look at S-Commerce adoption in SMEs from an organizational perspective (Abdulla Ali et al., 2019; Abed, 2020; Purwandari et al., 2019). At present, technology adoption for organizations is increasing. That's because of the important role of technology for business growth. TOE is a theory used to implement technology at the organizational level. TOE has three factor; technology, organization, and environment. In practice, TOE has been used massively because it is very systematic in examining the internal and external factors of an organization (Abed, 2020; Purwandari et al., 2019; Wang et al., 2019).

For instance, research conducted by Abed (2020) investigated the factors that influence the adoption of S-Commerce in SMEs in Saudi Arabia. In this research, on technology factors, focuses on perceived usefulness and security. On organizational factors focus on top management support and organizational readiness. Whereas the environmental factors 
focus on consumer pressure and trading partner pressure. The proposed conceptual model of this study can be seen in Figure 3. Six hypotheses in this study have a high correlation with the adoption of S-Commerce in SMEs in Saudi Arabia.

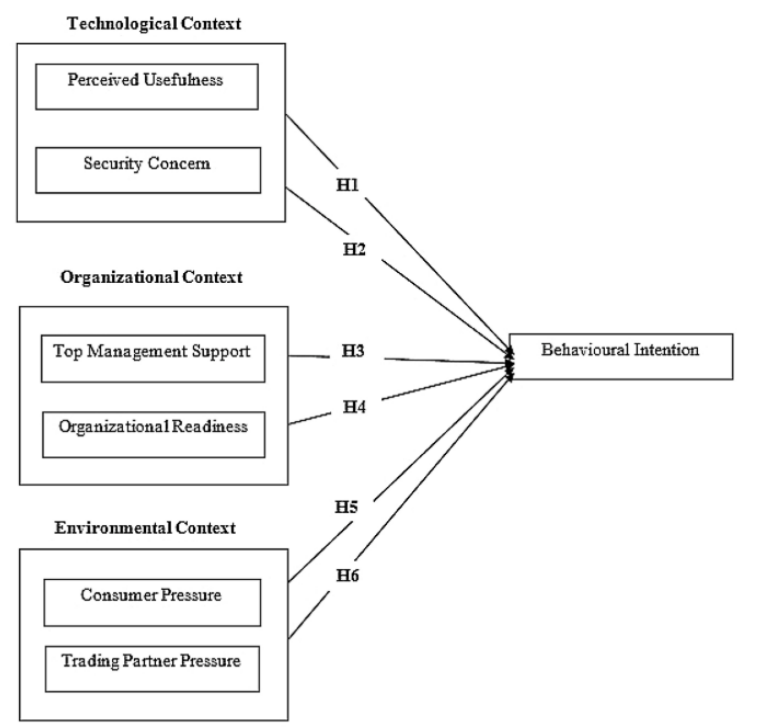

Figure 3. The Model Produced by Researchers (Abed, 2020)

The theory of TAM and UTAUT, habituated to investigate the adoption of technology from the individual level, while the TOE is usually to explain the application from the organizational level. Although TAM and UTAUT have proved to be effective in investigated technology acceptance for individuals, TAM is still valid and suitable investigating technology adoption in organizations including SMEs (Dahnil et al., 2014; Wang et al., 2019).

\section{Related Prior Research}

In this research, there were 22 previous research articles correlated to the adoption of S-Commerce in SMEs. The articles are from journals and conference proceedings from relevant databases between 2014 until 2020. These articles consist of 21 experimental studies and 1 review study article. Articles were obtained from several academic databases using the keywords social commerce, social commerce adoption, and social media marketing. Then, we ensure that the article fits our needs by investigating the factors and methods used for S-Commerce implementation. Table 1 shows the number of articles from each academic database. Figure 4 shows the number of articles per year relevant to this study.

Table 1. Number of articles from each database

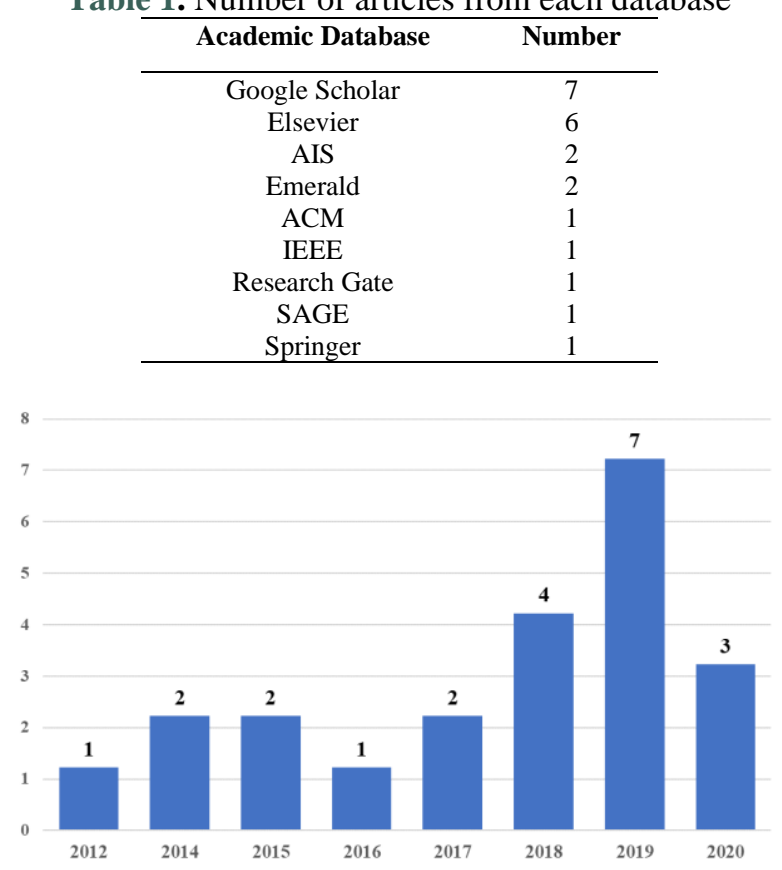

Figure 4. Number of articles per years 
In this section, ten frameworks will be discussed about current research as follows. Abed et al. (2015) conducted a study of what influences the adoption of S-Commerce technology in the context of Saudi Arabia. Conceptual models created using UTAUT by adding external factors such as risk, innovativeness, trust, and quality of information. The results of this study that the factors that influence the adoption of S-Commerce in Saudi Arabia are facilitating conditions, habits, trust, risk, innovativeness, and quality of information. Interesting factors in this research are habit and perceived risk. The habit of using technology and perceived risks that occur in online transactions is the point that also needs to be considered in the adoption of S-Commerce.

Dahnil et al (2014) research to determine the factors that drive the adoption of social media marketing in SMEs and organizations. The theory used by the researcher is TAM. The point that determine the designation of social media are perceived usefulness, ease of use, top management influence, technology compatibility, government influence, policy, and initiatives. The top management factor is very influential for SMEs for technology adoption because resources that are limited to SMEs must be addressed directly by the business owner. SMEs need to technology compatibility to effectively adopt S-Commerce.

Gatautis \& Medziausiene (2014) research to to determine the factors that drive the acceptance of S-Commerce in Lithuania. The theory used in this study is UTAUT because S-Commerce is associated with the utilization of social technology in wholesaling activities so that the acceptance of S-Commerce is related to the obtaining of social technology. The results of this research that the factors that drive the acceptance of S-Commerce in Lithuania are effort expectancy, performance expectancy, facilitating conditions, and social influence. Proposed research framework produced by researchers appears in the Figure 5.

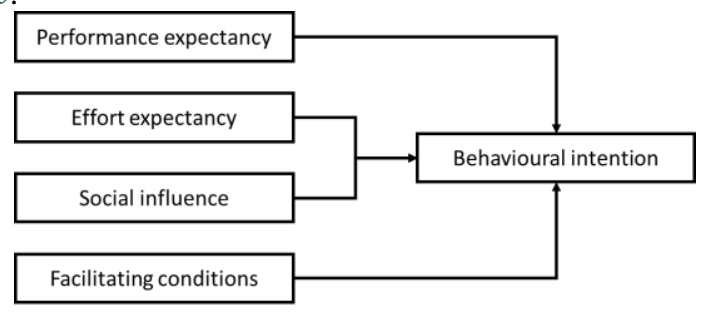

Figure 5. Empirically Validated Model of S-Commerce Acceptance (Gatautis \& Medziausiene, 2014)

Solangi et al (2019) investigates consumer behavior regarding the adoption of S-Commerce and models S-Commerce technology in small businesses in Pakistan. The point that determines the utilization of S-Commerce in Pakistan are perceived ease of use, perceived usefulness, social media influence, and risk. As stated by Abed et al (2015), researchers also believe that risk factors need to be considered related to unfavorable results of products and services provided in SCommerce. Proposed research framework produced by researchers appears in the Figure 6.

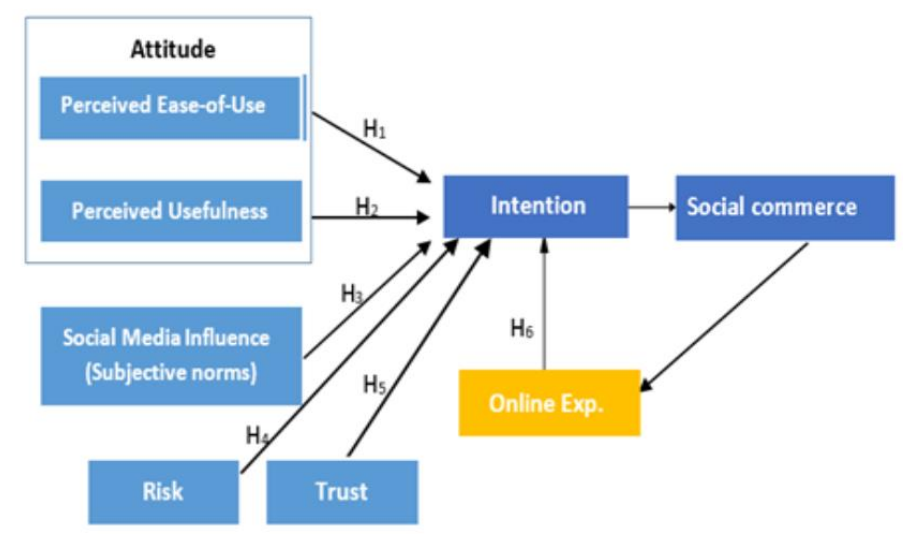

Figure 6. Proposed Research Framework (Solangi et al., 2019)

Cho \& Son (2019) research to determine the effect of social connectedness on the attitudes and intentions of social media users on the adoption of S-Commerce. The theory used in this research is TAM. The results of this study are perceived ease of use, perceived usefulness, and enjoyment. In this study, the enjoyment factor is important because someone who uses technology must feel comfortable when using technology. Proposed research framework produced by researchers appears in the Figure 7. 


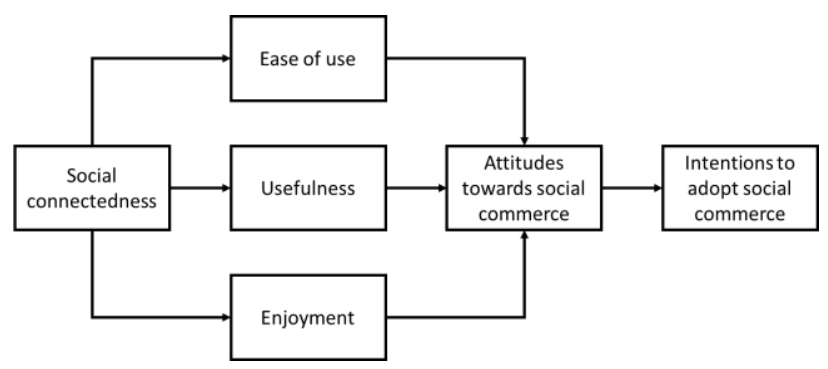

Figure 7. Proposed Research Framework (Cho \& Son, 2019)

Bamansoor et al (2020) using UTAUT to determine aspects of S-Commerce acceptance in Malaysia. The results of this study are the factors influential to the adoption of S-Commerce in Malaysia. The determining factors are social influence, performance expectancy, facilitating conditions, effort expectancy, habit, trust, hedonic, and culture. Proposed conceptual model produced by researchers appears in the Figure $\mathbf{8}$.

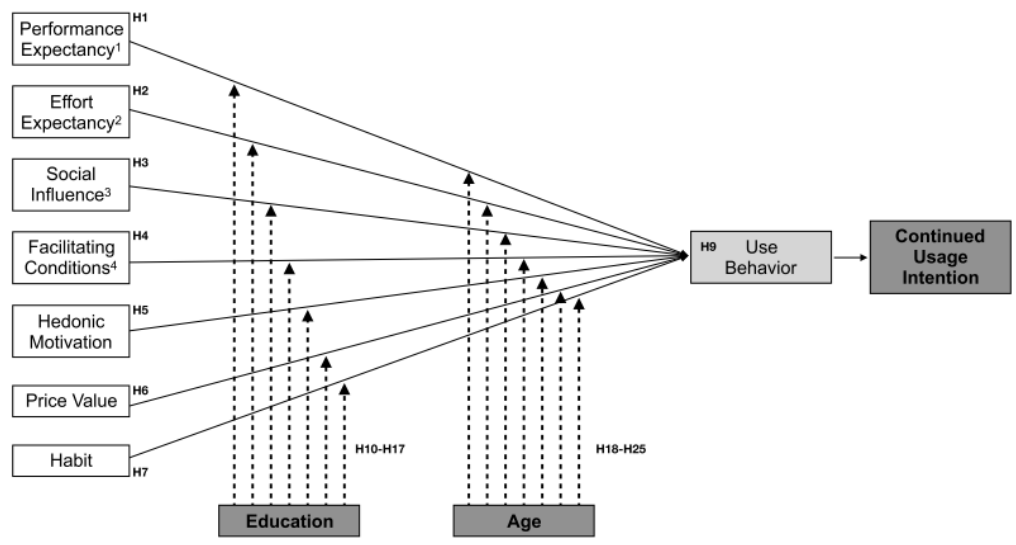

Figure 8. The Proposed Conceptual model (Bamansoor et al., 2020)

Chatterjee \& Kumar Kar (2020) research to identify the factors that can help SMEs in India to bring up social media marketing. The theory used in this research is TAM. The results of this study are that the factors that can help SMEs in India to the adoption of social media marketing are compatibility, perceived usefulness, and perceived ease of use. The interesting about the results of this study is compatibility. In the adoption of S-Commerce in SME, it is necessary to consider the compatibility between existing technology and new technology. This is important to avoid failure during implementation. The proposed conceptual models in this study are shown in the Figure 9.

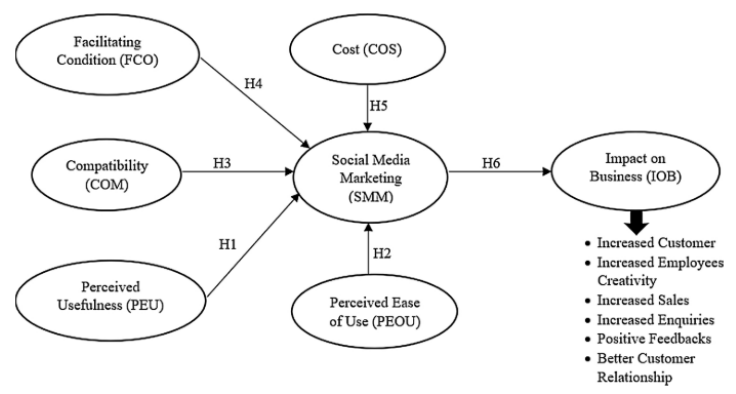

Figure 9. The Proposed Conceptual model (Chatterjee \& Kumar Kar, 2020)

Othman et al (2019) research to examine the factors that trigger consumers' intention to purchase by utilizing SCommerce in Malaysia. The theory used in this research is TAM. The results of this study that the factors that trigger utilizing S-Commerce in Malaysia are enjoyment, trust, perceived usefulness, quality, perceived value, security, comfort transaction and ease of use. The interesting thing in this research is the enjoyment factor. According to researchers, the enjoyment factor is interesting because the feeling of happiness when using S-Commerce will encourage customers to make purchases. This is like the research conducted by Cho \& Son (2019). The conceptual framework produced by the researcher is shown in Figure 10. 


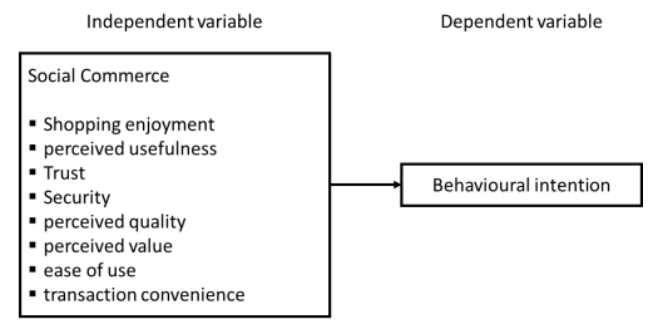

Figure 10. The Conceptual Framework Conducted by The Researcher (Othman et al., 2019)

Ben et al (2018) using UTAUT on his research to align business strategy and social media platforms for understanding the S-Commerce. The results of this study that the factors that increase S-Commerce intent are perceived ease of use, hedonic, habits, and facilitating conditions. Almost the same as expressed by Abed et al (2015) and Bamansoor et al (2020), habit factors also affect S-Commerce. In this study, researchers convey that habits are influenced by the price and reputation of vendors. The proposed research model appears in the Figure 11.

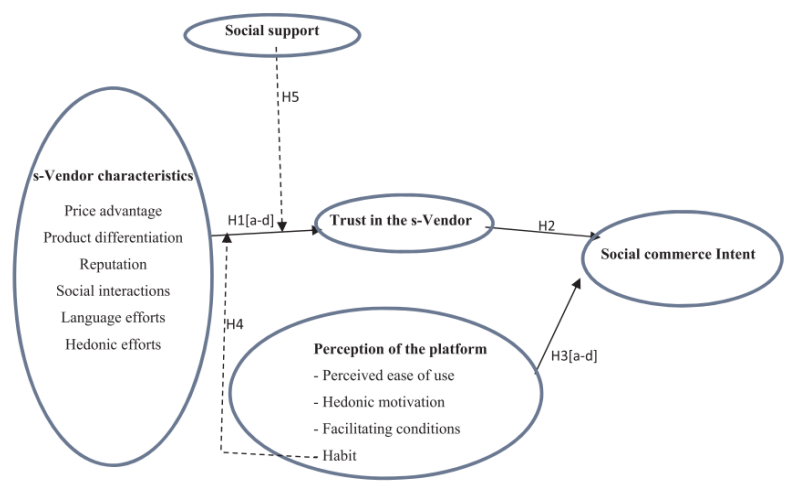

Figure 11. The Proposed Research Model (Ben et al., 2018)

Purwandari et al (2019) research to understand the factors that influence the adoption of e-marketplace and Instagram concerning the adoption of S-Commerce in SMEs in Indonesia. Researchers use TOE as a basis for research. TOE has chosen because it has been attaining used by previous studies in investigating factors that determine technology adoption of e-commerce. The results of this study show that the factors perceived benefit, top management support, competitive pressure, financial resources, vendor support, and perceived risk are effect SMEs to adopt e-marketplace. In this study, the top management support factor is very interesting. Because of this, at SMEs, all decisions are determined by the business owner. Thus, increased business owner IT capabilities, innovation capabilities, and the values of technology can drive adoption better. The proposed framework of this research can be shown in Figure 12.

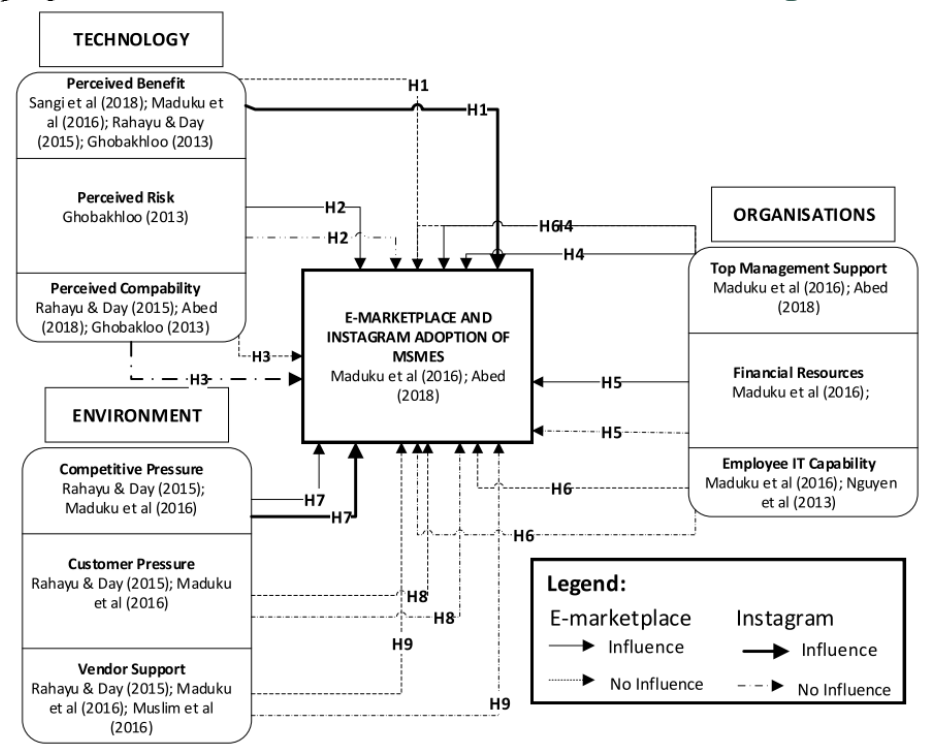

Figure 12. Proposed Framework of This Reasearch (Purwandari et al., 2019) 


\section{RELATED WORKS}

This section describes the theories used in previous studies. Some theories used are TAM, UTAUT, TPB, Delone, TOE, TRA, TTF, ECT, and also Social Network. TAM and UTAUT are the most widely used theories in this research, some of which are used simultaneously. TAM is often used because it is most effective for investigating technology acceptance and can be used in many studies about technology acceptance. TAM has two variables that are very important for technology adoption, namely usefulness and perceived ease of use (Chatterjee \& Kumar Kar, 2020; Cho \& Son, 2019; Dahnil et al., 2014).

Whereas UTAUT has facilitating conditions, effort expectancy, habit, hedonic, and trust (Abed et al., 2015; Bamansoor et al., 2020; Ben et al., 2018; Dahnil et al., 2014; Gatautis \& Medziausiene, 2014; Zamrudi \& Wicaksono, 2018).

Table 2 shows a summary of Related Work by Prior Research.

Table 2. Related Work by Prior Research

\begin{tabular}{|c|c|c|c|c|}
\hline No. & Author & Aim & Theory & Factors \\
\hline 1. & Abed (2020) & $\begin{array}{l}\text { This study aims to determine the aspect } \\
\text { that influences the adoption of S- } \\
\text { Commerce in SMEs in Saudi Arabia. }\end{array}$ & TOE & $\begin{array}{l}\text { Trading partner pressure, top management } \\
\text { support and perceived usefulness }\end{array}$ \\
\hline 2. & $\begin{array}{l}\text { Bamansoor et } \\
\text { al (2020) }\end{array}$ & $\begin{array}{l}\text { This research aims to determine aspects of } \\
\text { S-Commerce acceptance in Malaysia. }\end{array}$ & UTAUT & $\begin{array}{l}\text { Social influence, performance expectancy, } \\
\text { facilitating conditions, effort expectancy, habit, } \\
\text { trust, hedonic, and culture }\end{array}$ \\
\hline 3. & $\begin{array}{l}\text { Chatterjee \& } \\
\text { Kumar Kar } \\
\text { (2020) }\end{array}$ & $\begin{array}{l}\text { The research aims to identify the factors } \\
\text { that can help SMEs in India to adopt } \\
\text { social media marketing. }\end{array}$ & $\begin{array}{l}\text { TAM, } \\
\text { UTAUT }\end{array}$ & $\begin{array}{l}\text { Compatibility, perceived usefulness, and } \\
\text { perceived ease of use }\end{array}$ \\
\hline 4. & $\begin{array}{l}\text { Al-Adwan } \\
\text { (2019) }\end{array}$ & $\begin{array}{l}\text { This research aims to investigate the } \\
\text { aspect that influence consumers to adopt } \\
\text { S-Commerce. }\end{array}$ & TAM,TPB & $\begin{array}{l}\text { Familiarity, user experience, perceived } \\
\text { usefulness, perceived ease of use and trust. }\end{array}$ \\
\hline 5. & $\begin{array}{l}\text { Cho \& Son } \\
\text { (2019) }\end{array}$ & $\begin{array}{l}\text { This study aims to determine the effect of } \\
\text { social connectedness on the attitudes and } \\
\text { intentions of social media users on the } \\
\text { adoption of S-Commerce. }\end{array}$ & TAM & $\begin{array}{c}\text { Perceived ease of use, perceived usefulness, and } \\
\text { enjoyment }\end{array}$ \\
\hline 6. & $\begin{array}{l}\text { Othman et al } \\
\text { (2019) }\end{array}$ & $\begin{array}{c}\text { This study aims to determine the factors } \\
\text { that trigger consumers' intention to } \\
\text { purchase by utilizing S-Commerce in } \\
\text { Malaysia. }\end{array}$ & TAM & $\begin{array}{l}\text { Enjoyment, trust, perceived usefulness, quality, } \\
\text { perceived value, security, comfort transaction } \\
\text { and ease of use }\end{array}$ \\
\hline 7. & $\begin{array}{l}\text { Purwandari et } \\
\text { al (2019) }\end{array}$ & $\begin{array}{l}\text { This study aims to understand the factors } \\
\text { that influence the adoption of e- } \\
\text { marketplace and Instagram concerning the } \\
\text { adoption of S-Commerce in SMEs in } \\
\text { Indonesia. }\end{array}$ & TOE & $\begin{array}{l}\text { Perceived benefit, top management support, } \\
\text { competitive pressure, financial resources, } \\
\text { vendor support, and perceived risk }\end{array}$ \\
\hline 8. & $\begin{array}{l}\text { Samarasinghe } \\
\& \text { Silva (2019) }\end{array}$ & $\begin{array}{l}\text { This study aims to formulate a model to } \\
\text { examine consumer intentions of S- } \\
\text { Commerce }\end{array}$ & TAM & $\begin{array}{l}\text { Perceived usefulness and perceived ease } \\
\text { of use }\end{array}$ \\
\hline 9. & $\begin{array}{l}\text { Solangi et al } \\
\text { (2019) }\end{array}$ & $\begin{array}{l}\text { This study investigates consumer behavior } \\
\text { toward the adoption of S-Commerce and } \\
\text { models S-Commerce technology in small } \\
\text { businesses in Pakistan. }\end{array}$ & TAM,TRA & $\begin{array}{l}\text { Perceived ease of use, perceived usefulness, } \\
\text { social media influence and risk }\end{array}$ \\
\hline 10. & $\begin{array}{l}\text { Wijaya et al } \\
\text { (2019) }\end{array}$ & $\begin{array}{l}\text { This study proposed a model for } \\
\text { predicting and explaining behavior } \\
\text { intention use of S-Commerce that uses the } \\
\text { concept of customer experience and } \\
\text { expectation confirmation models }\end{array}$ & ECT, TAM & Perceived usefulness, and expectation \\
\hline 11. & $\begin{array}{l}\text { Aldhahery et } \\
\text { al. (2018) }\end{array}$ & $\begin{array}{l}\text { This study aims to empirically investigate } \\
\text { the factors that influence the } \\
\text { implementation of S-Commerce in Saudi } \\
\text { Arabia. }\end{array}$ & TAM & Perceived usefulness and trust \\
\hline 12. & $\begin{array}{l}\text { Ben et al } \\
(2018)\end{array}$ & $\begin{array}{l}\text { This study to align business strategy and } \\
\text { social media platforms for understanding } \\
\text { the S-Commerce }\end{array}$ & UTAUT & $\begin{array}{l}\text { Perceived ease of use, hedonic, habits, and } \\
\text { facilitating conditions }\end{array}$ \\
\hline 13. & $\begin{array}{l}\text { Maia et al } \\
(2018)\end{array}$ & $\begin{array}{l}\text { This study aims to determine the main } \\
\text { factors that influence consumers in S- } \\
\text { Commerce activities in Brazil. }\end{array}$ & TAM, DeLone & $\begin{array}{l}\text { Trust, perceived usefulness and information } \\
\text { quality }\end{array}$ \\
\hline 14. & $\begin{array}{l}\text { Zamrudi \& } \\
\text { Wicaksono } \\
\text { (2018) }\end{array}$ & $\begin{array}{l}\text { This study aims to investigate the attitude } \\
\text { of SMEs in the use of S-Commerce in the } \\
\text { province of South Kalimantan, Indonesia. }\end{array}$ & $\begin{array}{l}\text { TAM, TPB, } \\
\text { UTAUT }\end{array}$ & $\begin{array}{l}\text { Entrepreneurial expectation and facilitating } \\
\text { condition }\end{array}$ \\
\hline 15. & $\begin{array}{c}\text { Akman \& } \\
\text { Mishra (2017) }\end{array}$ & $\begin{array}{l}\text { This study aims to predict the factors that } \\
\text { influence the user's intention to adopt S- } \\
\text { Commerce. }\end{array}$ & $\begin{array}{l}\text { TAM, TRA, } \\
\text { Social Network }\end{array}$ & $\begin{array}{l}\text { Perceived trust, enjoyment/easiness, social } \\
\text { pressure, satisfaction and awareness. }\end{array}$ \\
\hline 16. & Lal (2017) & $\begin{array}{l}\text { This study investigate factors that } \\
\text { influence users of S-Commerce in India. }\end{array}$ & $\begin{array}{l}\text { Social Network, } \\
\text { Trust Transfer, } \\
\text { and TTF }\end{array}$ & $\begin{array}{l}\text { Informational support, community commitment, } \\
\text { trust, ease of use and service quality }\end{array}$ \\
\hline 17. & $\begin{array}{l}\text { Vongsraluang } \\
\& \text { Bhatiasevi } \\
\text { (2016) }\end{array}$ & $\begin{array}{l}\text { This research investigated to find out the } \\
\text { factors that influence the success of S- }\end{array}$ & Delone & System quality, service quality and trust. \\
\hline
\end{tabular}




\begin{tabular}{|c|c|c|c|c|}
\hline & & $\begin{array}{l}\text { Commerce in the context of SMEs in } \\
\text { Thailand. }\end{array}$ & & \\
\hline 18. & $\begin{array}{l}\text { Abed et al } \\
\text { (2015) }\end{array}$ & $\begin{array}{l}\text { This study is to determine the factors that } \\
\text { influence the adoption of S-Commerce } \\
\text { technology by users in the context of } \\
\text { Saudi Arabia. }\end{array}$ & UTAUT & $\begin{array}{l}\text { Facilitating conditions, habit, trust, risk, } \\
\text { innovativeness, and quality of information }\end{array}$ \\
\hline 19. & Alshibly (2015) & $\begin{array}{l}\text { This study identifies online service quality } \\
\text { and online trust as factors that influence } \\
\text { consumer perceived value in S- } \\
\text { Commerce. }\end{array}$ & DeLone & Trust, information quality and service quality \\
\hline 20. & $\begin{array}{l}\text { Dahnil et al } \\
\quad(2014)\end{array}$ & $\begin{array}{l}\text { This study aims to determine the factors } \\
\text { that drive the adoption of social media } \\
\text { marketing in SMEs and organizations }\end{array}$ & TAM, UTAUT & $\begin{array}{c}\text { Perceive usefullnes, ease of use, Top } \\
\text { management influence, technology } \\
\text { compatibility, government influence, policy and } \\
\text { initiatives. }\end{array}$ \\
\hline 21. & $\begin{array}{l}\text { Gatautis \& } \\
\text { Medziausiene } \\
\quad \text { (2014) }\end{array}$ & $\begin{array}{l}\text { This study aims to determine the factors } \\
\text { that drive the implementation of S- } \\
\text { Commerce in Lithuania. }\end{array}$ & UTAUT & $\begin{array}{l}\text { Performance expectancy, effort expectancy, } \\
\text { social influence and facilitating conditions }\end{array}$ \\
\hline 22. & Hajli (2012) & $\begin{array}{l}\text { This study proposes a model for the } \\
\text { adoption of S-Commerce based on } \\
\text { customer relationships on the internet and } \\
\text { social platforms to investigate customer } \\
\text { behavior. }\end{array}$ & TAM & Perceived usefulness, trust \\
\hline
\end{tabular}

In this study, 22 academic articles related to this field of research originating from journals and conference proceedings were used as a basis for knowing the factors that attaining the adoption of S-Commerce by SMEs. The results related to these factors can be shown in Table 3 .

According to the prior research, there are important factors for the adoption of S-Commerce in SME. Two factors that are most determinants of S-Commerce adoption are perceived usefulness (Abed, 2020; Al-Adwan, 2019; Aldhahery et al., 2018; Chatterjee \& Kumar Kar, 2020; Cho \& Son, 2019; Dahnil et al., 2014; Hajli, 2012; Maia et al., 2018; Othman et al., 2019; Purwandari et al., 2019; Samarasinghe \& Silva, 2019; Solangi et al., 2019; Wijaya et al., 2019) and trust (Abed et al., 2015; Akman \& Mishra, 2017; Al-Adwan, 2019; Aldhahery et al., 2018; Alshibly, 2015; Bamansoor et al., 2020; Hajli, 2012; Lal, 2017; Maia et al., 2018; Othman et al., 2019; Vongsraluang \& Bhatiasevi, 2016).

Other factors that determine the adoption of S-Commerce are ease of use (Al-Adwan, 2019; Ben et al., 2018; Chatterjee \& Kumar Kar, 2020; Cho \& Son, 2019; Dahnil et al., 2014; Lal, 2017; Othman et al., 2019; Samarasinghe \& Silva, 2019; Solangi et al., 2019) facilitating conditions (Abed et al., 2015; Bamansoor et al., 2020; Ben et al., 2018; Gatautis \& Medziausiene, 2014; Zamrudi \& Wicaksono, 2018), and information quality (Abed et al., 2015; Alshibly, 2015; Maia et al., 2018; Vongsraluang \& Bhatiasevi, 2016).

Table 3. Summary of Most Frequently Referred Variables

\begin{tabular}{|c|c|c|c|c|c|c|c|c|c|c|c|c|c|c|c|c|}
\hline Factors & $\begin{array}{l}\text { Pe } \\
\text { rf } \\
\text { or } \\
\text { m } \\
\text { an } \\
\text { ce } \\
\text { ex } \\
\text { pe } \\
\text { ct } \\
\text { an } \\
\text { cy }\end{array}$ & $\begin{array}{l}\text { Ef } \\
\text { fo } \\
\text { rt } \\
\text { ex } \\
\text { pe } \\
\text { ct } \\
\text { an } \\
\text { cy }\end{array}$ & $\begin{array}{c}\text { So } \\
\text { ci } \\
\text { al } \\
\text { in } \\
\text { fl } \\
\text { ue } \\
\text { nc } \\
\text { e }\end{array}$ & $\begin{array}{c}\text { Fa } \\
\text { cil } \\
\text { ita } \\
\text { ti } \\
\text { ng } \\
\text { co } \\
\text { nd } \\
\text { iti } \\
\text { on } \\
\text { s }\end{array}$ & $\begin{array}{l}\text { H } \\
\text { ed } \\
\text { on } \\
\text { ic }\end{array}$ & $\begin{array}{c}\text { H } \\
\text { ab } \\
\text { it }\end{array}$ & $\begin{array}{c}\text { Pe } \\
\text { rc } \\
\text { ei } \\
\text { ve } \\
\text { d } \\
\text { Us } \\
\text { ef } \\
\text { ul } \\
\text { ne } \\
\text { ss }\end{array}$ & $\begin{array}{c}\mathrm{E} \\
\mathrm{xp} \\
\mathbf{e c} \\
\text { ta } \\
\text { tio } \\
\mathbf{n}\end{array}$ & $\begin{array}{c}\mathbf{T r} \\
\text { us } \\
\mathbf{t}\end{array}$ & $\begin{array}{c}\text { Pe } \\
\text { rc } \\
\text { ei } \\
\text { ve } \\
\text { d } \\
\text { ris } \\
\mathbf{k}\end{array}$ & $\begin{array}{c}\text { In } \\
\text { fo } \\
\mathbf{r} \\
\mathbf{m} \\
\text { ati } \\
\text { on } \\
\mathbf{Q} \\
\text { ua } \\
\text { lit } \\
\mathbf{y}\end{array}$ & $\begin{array}{c}\text { Se } \\
\text { rv } \\
\text { ic } \\
\text { e } \\
\text { Q } \\
\text { ua } \\
\text { lit } \\
\text { y }\end{array}$ & $\begin{array}{c}E \\
\text { nj } \\
\text { oy } \\
\text { m } \\
\text { en } \\
\text { t }\end{array}$ & $\begin{array}{c}\mathbf{E} \\
\text { as } \\
\text { e } \\
\text { of } \\
\text { Us } \\
\text { e }\end{array}$ & $\begin{array}{c}\text { T } \\
\text { op } \\
\text { m } \\
\text { an } \\
\text { ag } \\
\text { e } \\
\text { m } \\
\text { en } \\
\text { t }\end{array}$ & $\begin{array}{c}\text { Te } \\
\text { ch } \\
\text { no } \\
\text { lo } \\
\text { gy } \\
\text { co } \\
\text { m } \\
\text { pa } \\
\text { ti } \\
\text { bil } \\
\text { ity }\end{array}$ \\
\hline Abed (2020) & & & & & & & $\sqrt{ }$ & & & & & & & & $\sqrt{ }$ & \\
\hline Bamansoor et al (2020) & $\sqrt{ }$ & $\sqrt{ }$ & $\sqrt{ }$ & $\sqrt{ }$ & $\sqrt{ }$ & $\sqrt{ }$ & & & $\sqrt{ }$ & & & & & & & \\
\hline Chatterjee \& Kumar Kar (2020) & & & & & & & $\sqrt{ }$ & & & & & & & $\sqrt{ }$ & & $\sqrt{ }$ \\
\hline Al-Adwan (2019) & & & & & & & $\sqrt{ }$ & & $\sqrt{ }$ & & & & & $\sqrt{ }$ & & \\
\hline Cho \& Son (2019) & & & & & & & $\sqrt{ }$ & & & & & & $\sqrt{ }$ & $\sqrt{ }$ & & \\
\hline Othman et al (2019) & & & & & & & $\sqrt{ }$ & & $\sqrt{ }$ & & & & $\sqrt{ }$ & $\sqrt{ }$ & & \\
\hline Purwandari et al (2019) & & & & & & & $\sqrt{ }$ & & & $\sqrt{ }$ & & & & & $\sqrt{ }$ & \\
\hline Samarasinghe \& Silva (2019) & & & & & & & $\sqrt{ }$ & & & & & & & $\sqrt{ }$ & & \\
\hline Solangi et al (2019) & & & & & & & $\sqrt{ }$ & & & $\sqrt{ }$ & & & & $\sqrt{ }$ & & \\
\hline Wijaya et al. (2019) & & & & & & & $\sqrt{ }$ & $\sqrt{ }$ & & & & & & & & \\
\hline Aldhahery et al. (2018) & & & & & & & $\sqrt{ }$ & & $\sqrt{ }$ & & & & & & & \\
\hline Ben et al (2018) & & & & $\sqrt{ }$ & $\sqrt{ }$ & $\sqrt{ }$ & & & & & & & & $\sqrt{ }$ & & \\
\hline Maia et al. (2018) & & & & & & & $\sqrt{ }$ & & $\sqrt{ }$ & & $\sqrt{ }$ & & & & & \\
\hline Zamrudi \& Wicaksono (2018) & & & & $\sqrt{ }$ & & & & $\sqrt{ }$ & & & & & & & & \\
\hline Akman \& Mishra (2017) & & & & & & & & & $\sqrt{ }$ & & & & $\sqrt{ }$ & & & \\
\hline Lal (2017) & & & & & & & & & $\sqrt{ }$ & & & $\sqrt{ }$ & & $\sqrt{ }$ & & \\
\hline
\end{tabular}


Vongsraluang \& Bhatiasevi (2016)

Abed et al. (2015)

Alshibly (2015)

Dahnil et al (2014)

Gatautis \& Medziausiene (2014)

Hajli (2012)

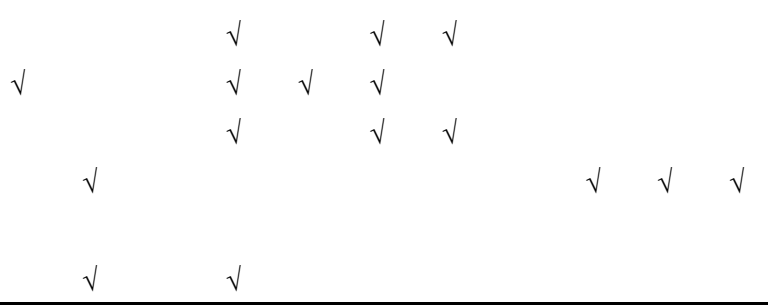

Based on Table 3, the factors of perceived usefulness, ease of use, and trust are the dominant factors in the articles from 2018 to 2020. Based on this, the adoption of S-Commerce requires a social and technical approach. These two things are like research conducted by Al-Adwan (2019). Besides, the factors of facilitating conditions and information quality also influence user understanding, improve user experience, increase intention to use, and user trust in S-Commerce adoption.

\section{DISCUSSION AND CONCLUSION}

Based on the factors that influence the implementation of S-Commerce which can be seen in Table 3, the perceived usefulness and trust are the most influential factors. Whereas ease of use, facilitating conditions, and information quality are factors that influence user belief using S-Commerce. According to Maia et al (2018), perceived usefulness and trust are the influential factors as the basis for the human interaction and the interchange relations. These factors make the person believe that the other party is doing their duty properly.

Other results in this study are, most theories that are often used in the adoption of S-Commerce are TAM and UTAUT. According to Dahnil (2014), TAM and UTAUT are effective for investigating technology adoption for individuals, but also that theories were valid and more suitable use in investigating technology adoption in organizations such as SMEs. Besides that, according to Purwandari (2019), TOE theory can also be used to investigate technology adoption. This is because the TOE has three variables that look at the organization from an internal or external perspective.

In previous studies, the implementation of S-Commerce was based more on individual perspectives than on company perspectives. For further research, it is also necessary to investigate the implementation of S-Commerce from the perspective of the organization.

\section{REFERENCES}

Abdulla Ali, W., Mukhtar, M., \& Mohamed, I. (2019). Validating the factors influencing social commerce adoption in small and medium enterprise in Malaysia. Indonesian Journal of Electrical Engineering and Computer Science, 17(1), $440-447$. https://doi.org/10.11591/ijeecs.v17.i1.pp440-447

Abed, S., Dwivedi, Y., \& Williams, M. (2015). Social Commerce Adoption by Saudi Consumers : A Conceptual Model. UK Academy for Information Systems Conference Proceedings 2015, 6.

Abed, S. S. (2020). Social commerce adoption using TOE framework: An empirical investigation of Saudi Arabian SMEs. International Journal of Information Management, 53(March). https://doi.org/10.1016/j.ijinfomgt.2020.102118

Akman, I., \& Mishra, A. (2017). Factors influencing consumer intention in social commerce adoption. Information Technology and People, 30(2), 356-370. https://doi.org/10.1108/ITP-01-2016-0006

Al-Adwan, A. S. (2019). Revealing the Influential Factors Driving Social Commerce Adoption. Interdisciplinary Journal of Information, Knowledge, and Management, 14(1), 295-324. https://doi.org/https://doi.org/10.28945/4438

Aldhahery, M., Khuhro, M. A., \& Maher, Z. A. (2018). Investigation of Adoption Behaviour for Social Commerce in the Kindom of Saudi Arabia. 2018 IEEE 5th International Conference on Engineering Technologies and Applied Sciences (ICETAS), 1-4.

Alshibly, H. H. (2015). Customer Perceived Value in Social Commerce: An Exploration of Its Antecedents and Consequences. Journal of Management Research, 7(1), 17. https://doi.org/10.5296/jmr.v7i1.6800

Bamansoor, S., Saany, S. I. A., \& El-Ebiary, Y. A. B. (2020). The S-Commerce Usage and Acceptance Modelling in Malaysia. 3C TIC: Cuadernos de Desarrollo Aplicados a Las TIC, 9(1), 99-115. https://doi.org/10.17993/3ctic.2020.91.99-115

Ben, I., Al-neama, N., \& Kerbache, L. (2018). Investigating the drivers for social commerce in social media platforms : Importance of trust, social support and the platform perceived usage. Journal of Retailing and Consumer Services, 41(September 2017), 1119. https://doi.org/10.1016/j.jretconser.2017.10.021

Chatterjee, S., \& Kumar Kar, A. (2020). Why do small and medium enterprises use social media marketing and what is the impact: Empirical insights from India. International Journal of Information Management, 53(February). https://doi.org/10.1016/j.ijinfomgt.2020.102103

Cho, E., \& Son, J. (2019). The effect of social connectedness on consumer adoption of social commerce in apparel shopping. Fashion and Textiles, 6(1). https://doi.org/10.1186/s40691-019-0171-7

Dahnil, M. I., Marzuki, K. M., Langgat, J., \& Fabeil, N. F. (2014). Factors Influencing SMEs Adoption of Social Media Marketing. Procedia - Social and Behavioral Sciences, 148, 119-126. https://doi.org/10.1016/j.sbspro.2014.07.025

Davis, F. D. (1985). A Technology Acceptance Model For Empirically Testing New End-User Information Systems: Theory And Results [Massachusetts Institute Of Technology]. In Management (Issue May). https://doi.org/oclc/56932490

Gatautis, R., \& Medziausiene, A. (2014). Factors Affecting Social Commerce Acceptance in Lithuania. Procedia - Social and Behavioral Sciences, 110(2013), 1235-1242. https://doi.org/10.1016/j.sbspro.2013.12.970

Hajli, M. (2012). Social Commerce Adoption Model. UK Academy for Information Systems Conference. http://aisel.aisnet.org/ukais2012\%0Ahttp://aisel.aisnet.org/ukais2012/16

Johny, A., \& M.Bhasi. (2015). An Integrated Model of Factors Affecting Information Technology Implementation Success in Organizations. International Journal of Engineering and Management Research, 5(2), 81-89. 
Lal, P. (2017). Analyzing determinants influencing an individual's intention to use social commerce website. Future Business Journal, 3(1), 70-85. https://doi.org/10.1016/j.fbj.2017.02.001

Lin, J., Luo, Z., Cheng, X., \& Li, L. (2019). Understanding the interplay of social commerce affordances and swift guanxi: An empirical study. Information and Management, 56(2), 213-224. https://doi.org/10.1016/j.im.2018.05.009

Lin, X., Li, Y., \& Wang, X. (2017). Social commerce research : Definition, research themes and the trends. International Journal of Information Management, 37(3), 190-201. https://doi.org/10.1016/j.ijinfomgt.2016.06.006

Maia, C., Lunardi, G., Longaray, A., \& Munhoz, P. (2018). Factors and characteristics that influence consumers' participation in social commerce. Revista de Gestão, 25(2), 194-211. https://doi.org/10.1108/rege-03-2018-031

Othman, A. K., Hassan, L. F. A., Hamzah, M. I., Razali, A. R., Saim, M. A. S., Ramli, M. S., Osman, M. A., \& Azhar, M. A. A. (2019). The Influence of Social Commerce Factors on Customer Intention to Purchase. Asian Themes in Social Sciences Research, 3(1), 1-10. https://doi.org/10.33094/journal.139.2019.31.1.10

Purwandari, B., Otmen, B., \& Kumaralalita, L. (2019). Adoption factors of e-marketplace and instagram for micro, small, and medium enterprises (MSMEs) in Indonesia. ACM International Conference Proceeding Series, 111-116. https://doi.org/10.1145/3352411.3352453

Rahman, N. S. A., Rosman, A. N., \& Sahabudin, N. A. (2020). Students' Continuance of Using E-Learning System: A Review of Conceptual Frameworks. IOP Conference Series: Materials Science and Engineering, 769. https://doi.org/10.1088/1757$899 \mathrm{x} / 769 / 1 / 012044$

Samarasinghe, S., \& Silva, K. (2019). Social Commerce Acceptance : Integrated Model with Collaboration Theories and Technology Acceptance Model. American Scientific Research Journal for Engineering, Technology, and Sciences, 62(1), 39-53.

Solangi, Y. A., Solangi, Z. A., Maher, Z. A., Abd. Aziz, M., Hamzah, M. S., \& Shah, A. (2019). Revised and Extended Social Commerce Technology Adoption in e-business of Pakistan. International Journal on Perceptive and Cognitive Computing, 5(2), 52-58. https://doi.org/10.31436/ijpcc.v5i2.115

Vongsraluang, N., \& Bhatiasevi, V. (2016). The determinants of social commerce system success for SMEs in Thailand. Information Development, 33(1), 80-96. https://doi.org/10.1177/0266666916639632

Wang, Y., Jin, L., \& Mao, H. (2019). Farmer Cooperatives Intention to Adopt Agricultural Information Technology — Mediating Effects of Attitude. Information Systems Frontiers, 20(95), 1-16.

Wijaya, I. W. K., Rai, A. A. G., \& Hariguna, T. (2019). The impact of customer experience on customer behavior intention use in social media commerce, an extended expectation confirmation model: An empirical study. Management Science Letters, 9(2019), 2009-2020. https://doi.org/10.5267/j.msl.2019.7.005

Zamrudi, Z., \& Wicaksono, T. (2018). Social Commerce Adoption in SME's. JEMA: Jurnal Ilmiah Bidang Akuntansi Dan Manajemen, 15(2), 60. https://doi.org/10.31106/jema.v15i2.1125

Zhang, K. Z. K., \& Benyoucef, M. (2016). Consumer behavior in social commerce: A literature review. Decision Support Systems, 86, 95-108. https://doi.org/10.1016/j.dss.2016.04.001

\section{ACKNOWLEDGEMENT}

The authors would like to thank Universitas Dinamika for sponsoring this work. 